\title{
Paradoxes of Gendered Rurality, Women's Non-Economic Constructions, Disempowerment and State Capitalism in South Africa
}

\author{
Johannes Tsheola \\ University of Limpopo, South Africa \\ johannes.tsheola@ul.ac.za
}

Doi:10.5901/ajis.2014.v3n1p315

\begin{abstract}
Capitalist development in most developing countries has allowed for incomplete restructuring of the gendered rural spaces, thereby sustaining the exploitation of the perceived separation between the private household as social sphere and the public community as economic domain. The deeply gendered rurality, together with the masculine constructions of the hegemonic state capitalism, obscured and underrated rural women's multiple development practices and contributions as non-economic subsidy to capitalist development. Under state capitalism, the state and traded capital derive benefits from feminization of the public community economic sphere whilst sustaining a strong association between rurality, women, private social household and communitarianism. This paper argues that state capitalism retained neoliberal market ethos, negating state activism, resulting into an inherently hostile environment to authentic rural women empowerment. Within the gendered rurality, constructed through colonialism and accentuated under apartheid capitalism, such state capitalism renders women-oriented projects paradoxical as they tend to re-enforce women disempowerment.
\end{abstract}

Keywords: state capitalism; private social household; public economic community; gendered rurality; women empowerment; South Africa

\section{Introduction}

Rural households in developing countries such as South Africa are generally highly vulnerable to the risks associated with poverty because they lack the necessary instruments for adequately managing the deteriorating ecological and macroeconomic circumstances (Tsheola, 2012). The primacy of rural livelihoods as "one of the key pillar(s) in an effective and sustainable rural poverty-reduction strategy" (Anderson, 2003, p.161) is unquestionable. Evidence show that over the years, "theoretical frameworks and operational models of how the poverty situation could be transformed" (Mabogunje, 1989, p.14) were formulated and implemented, but that rural populations in developing countries remain exposed to the harsh neoliberal capitalist development and the consonant ecological crises (Eshete, 1992; Tsheola, 2012). Decades of thinking and evolution of mechanisms for the "eradication" of rural poverty have produced skeletal interventions over rural landscapes, fraught with obstacles that militate against the transformation of the colonial strictures (Nabudere, 2006; Bado, 2012; Tsheola, 2012). The recent rush towards adoption of state capitalism and collusion of the state and capital in developing countries is destined to perpetuate discriminatory gendered rurality and disempowerment of women for continued subsidy to capitalist development.

Historically, rural men and women have different experiences of rurality because the socio-economic activities and circumstances therein, as well as ascriptions of value and worth, are all gendered and classed (Bryant and Pini, 2009). Women's lives continue to be constructed through tacit scripts of communitarianism within rural spaces wherein gender is "strongly internalized .... experienced and performed across spaces and intricately embedded in social structures and power relations" (Bryant and Pini, 2009, p.48). Given the preeminence of masculine constructions within the hegemonic macroeconomics (Koissy-Kpein, 2012), women have continued to be the most vulnerable to rural poverty, amidst the rhetoric of women empowerment and skeletons of failed women-oriented projects (Tsheola, 2012). Equally, the collusion between the state and capital under state capitalism does not seek to transform the masculine constructions of the modern economies, with the result that colonial gendered rurality and discrimination against women persists in the modern capitalist development.

In rural South Africa, which adopted state capitalism since at least 2000 (Tsheola and Sebola, 2012), Limpopo Province's rural populations reside within tribal settlements of the former Bantustans wherein colonialism and apartheid destroyed the asset base and reinforced a strong correlation between poverty and gender (Tsheola, 2012). Eradication of 
rural poverty there is intricately interlocked with rural women empowerment (Tsheola, 2012). The democratic state has, understandably, implemented women-oriented projects in order to "train women in the management of a socially acceptable and successful female biography;" in the hope of assisting them to "lead a self-determined life in which gainful employment plays an important role;" and, to fight "their social exclusion" and "polarization" (Aufhauser and Hafner, 2002, pp.258, 259). Whereas poor rural women have always survived through a plurality of self-generated livelihoods, which have been disproportionately impacted upon by the harsh ecological and macroeconomic circumstances (Bryceson, 1997, 1999, 2000; Francis, 2000, 2002), the harsh realities occasioned by colonization and bantustanization are presently exacerbated through the Growth, Employment \& Redistribution (GEAR) macroeconomics (Tsheola, 2012) and state capitalism (Tsheola and Sebola, 2012). Consequently, the state's rural women-oriented projects which had hoped to "integrate" women into the male-dominated economic spaces through independent female biographies, are however alien to the former Bantustan localities. Paradoxically, these projects have reproduced women's vulnerability to poverty.

This paper argues that the gendered rurality, which entails the primacy of women-orientated rural development in South Africa's former Bantustans, equally enforces perpetuation of non-economic constructions of women in the public domain of community spaces under state capitalism. It demonstrates the paradoxes of rural women empowerment interventions within the deeply gendered rurality. The next section analyses the conceptual frameworks underlying the failure of women-oriented projects within the context of state capitalism. The theoretical debate teases out the dynamics involved in the interface between development projects and women empowerment within the deeply gendered rurality, communitarianism and non-economic constructions of rural women's lives through the artificial separation of the private social households from the public economic community sphere. South Africa's rural development policy paradox and Limpopo Province's contexts are discussed in section three in order to contextualize a typical rural village within the geographic area of the former Bantustan.

\section{Gendered Rurality, Communitarianism, Women Disempowerment and State Capitalism}

Although experiences of rural poverty vary along gender, age, race and other divides, some rural studies have strongly argued that class analysis itself underrates intra-class differences, experiences and ability to adapt (Marsden, 1990; Bryant and Pini, 2009). However, there is credence to the notion that the intersections between gender and class are intricate and significant, and that systems of patriarchy cannot be understood in isolation from the overarching capitalism structure (Poiner, 1990; Dempsey, 1992; Hanson and Pratt, 1995; Gibson-Graham, 1996; Bob, 2001; Aufhauser and Hafner, 2002; Hey, 2003; McDowell, 2006; Hoggart, 2007; Phillips, 2007; Bryant and Pini, 2009). Under state capitalism and bureaugarchs in a democratic South Africa, for example, public policies have inadvertently come to legitimize the apartheid status quo of stark inequalities and lopsided experiences of poverty by rural populations, the majority of whom are women (Tsheola and Sebola, 2012). For this reason, adoption of state capitalism in developing countries should shed crucial insights about the persistence of gender discrimination against women under democratic dispensation and hegemonic neoliberal capitalist development. This paper holds that at the point of collusion of bureaugarchs (politicians and capitalists), the state and capital continue to construct women as non-economic in order to ensure a "democratically" guaranteed socio-economic subsidy for capitalist development.

\subsection{State Capitalism: the Visible Hand Macroeconomics}

Since the 1990s, the preoccupation with "active destruction and discreditation of Keynesian-welfare and social-collectivist institutions" was superseded by "purposeful construction and consideration of neo-liberalized state forms, model of governance and regulatory relations" (Peck and Tickell, 2001, p.4 in Smith, 2004, p.379). By adopting state capitalism, developing countries effectively ceded the freedom of state activism necessary for crafting adequate social policies and implementing them vigorously to support the poor (Tsheola and Sebola, 2012). South Africa established state capitalism since at least 2000 as the liberalization principles of GEAR increasingly took pragmatic effect in the economy and political content of the society (Tsheola and Sebola, 2012). As a result, rural development and women empowerment too came to be captivated by the same politics of the "magic of the market, the survival of the fittest and the evils of the state" (Wooldridge, 2012, p.3). As rural development in the most impoverished sectors of the society such as the former Bantustans was increasingly subjugated under harsh challenges of reconciling public and private values that are sometimes deeply contradictory, rural women came to experience the worst effects of the collusion of the state and capital that perpetuated their non-economic constructions for capitalist development.

There are at least three ideological traditions about development and political thinking: liberal capitalism, state 
socialism and state capitalism (Midgley, 1999; Hettne, 1995; Peet, 2002; Hall and Midgley, 2004; Tsheola and Sebola, 2012). Under liberal capitalism, the economic system is reliant on market forces, gradual industrialization, private investments derived from profit-making, low wage levels and emphasis on technological advancement, capital accumulation and market expansion (Hettne, 1995; Midgley, 1999; Peet, 2002; Hall and Midgley, 2004; Tsheola and Sebola, 2012). In state socialism, investment is closely concentrated on developing a strong base of heavy industry, rather than manufacturing consumer goods, which is monopolised by the state through central planning processes, rather than individual capitalists searching for profit (Hettne, 1995; Midgley, 1999; Peet, 2002; Hall and Midgley, 2004; Tsheola and Sebola, 2012). State capitalism, which is of interest to this paper, grants the state a responsibility for the stability and continuous growth of capitalism on the assumption that the markets do not have the capacity for self-regulation (Hettne, 1995; Midgley, 1999; Peet, 2002; Hall and Midgley, 2004; Tsheola and Sebola, 2012). These ideological traditions are aligned to distinctive approaches that emphasize the role of the market, the state and communities in societal development, respectively (Midgley, 1999; Peet, 2002; Hall and Midgley, 2004; Tsheola and Sebola, 2012).

Accordingly, the three ideological traditions have exerted strong normative influence on social policy as individualism and enterprise-orientation (liberal capitalism), reformism and collectivism or statism (state socialism) as well as structuralism and populism or bottom-up action (state capitalism), (Midgley, 1999; Hall and Midgley, 2004; Tsheola and Sebola, 2012). The enterprise approach emphasises the fundamental importance and centrality of the individual in social life as well as the primacy of the market in development, wherein private commercial companies are encouraged to perform essential public functions and services such as health, education, social security and housing (Midgley, 1999; Hall and Midgley, 2004; Tsheola and Sebola, 2012). On its part, statism involves collectivism with the assumption that "the best society is one in which people cooperate to meet their common needs" (Hall and Midgley, 2004, p.28). In practice, state socialism has however been synonymous with conflicts regarding the direction of central planning, deteriorating into autocracy (Midgley, 1999; Clapham, 2001, 2002; Peet, 2002; Hall and Midgley, 2004; Hammett, 2010; Tsheola and Sebola, 2012). Given the evident drawbacks of liberal capitalism and state socialism, populism was touted as an alternative that held the qualities of counteracting statist tendency towards autocracy and that the democratization of the state would inevitably invoke development.

Notwithstanding the currency of the bottom-up rhetoric, the practice of populism as community development, which gained ascendency and manifested as the interface of statism and enterprise approach since the 1980s, has uniformly been tenuous and elusive across the developing world. In practice, state capitalism redefined the role of the state as derivative wherein its scope and content became functions of the efficiency of markets (Tsheola and Sebola, 2012). From the political-economy perspective, the market and its assumed rationality are thought to be the economic sphere whilst the state provides the political content, wherein "politics and economics do not refer to qualitatively different objects" (Caporaso and Levine, 1992, p.220). State capitalism merely accorded value to the market, wherein capitalists alone continued to receive surplus, thereby precipitating virtual commercialization, corporatization and privatization of society (Midgley, 1999; Peet, 2002; Hall and Midgley, 2004; Smith, 2004; Tsheola and Sebola, 2012). That is, state capitalism (re)defined public interest as the politicians and/or government professionals' expression of what is best for society, with the result that an unprecedented coming together of the state and capital reinvented the free market ethos through the visible hand of the state (Tsheola and Sebola, 2012). The resultant state-market collusion thwarted state activism for the poor, especially the rural populations and women.

By its nature, state capitalism virtually eliminates politicians from the decision-making processes about redistributive justice (Smith, 2004; Tsheola and Sebola, 2012), thereby condemning poor people, especially rural women, to persistent poverty. Under state capitalism, social policy formulation essentially shifts from the political processes to the technocratic professional planners' efficacies (Smith, 2004; Tsheola and Sebola, 2012). That is, state capitalism allows government to make economic decisions that embrace globalization and "capitalist tools" to promote economic growth and development (Wooldridge, 2012), with the paradoxical imperative that powerless developing "states must become more 'socially-interventionist', while still trying to remain 'globally competitive' in an international system that promotes deregulation" (Smith, 2004, p.379). Inevitably, the private market logic underlying liberal capitalism persisted (Smith, 2004; Tsheola and Sebola, 2012), meaning that "the invisible hand of the market is giving way to the visible, and often authoritarian, hand of state capitalism" (Wooldridge, 2012, p.5). This shift perpetuates the status quo of socio-economic exclusions against poor people, especially rural populations and women. Unsurprisingly, national pronouncements of better life and access for all have remained hollow in post-apartheid South Africa's life-story, which is currently riddled with distributional dilemmas engendered by the state-market paralysis (Tsheola and Sebola, 2012).

Notwithstanding its rhetorical commitment to the national democratic revolution (NDR) and Freedom Charter principles, the ruling African National Congress (ANC) has been overwhelmed by pragmatism which enforced the 
converse where technocratic efficiency predominated development decisions wherein fiscal austerity was prioritised above redistributive justice (Bond, 1999; Smith, 2004; Tsheola and Sebola, 2012). Ironically, the ANC-led state's reverence of neo-libertarianism and the establishment of state capitalism have been palatable, in stark contrast to its NDR and Freedom Charter commitments (Tsheola and Sebola, 2012). Poor South Africans, especially the rural populations and women (Tsheola, 2012), came to be confronted with the public-private market distributional dilemmas of balancing "efficiency and equity ... objectives" (Smith, 2004, p.375). The societal development interests have generally remained divergent and delusional where chronic poverty and ineptitude have persisted (Bond, 1999, 2004; Tsheola, 2012; Tsheola and Sebola, 2012). Rural women constitute the sector of the population that is disproportionately vulnerable to severe effects of poverty, at the same time as the requirement to establish independent female biographies through state-sponsored women-oriented projects embodies intractable paradoxes of perpetuating women's colonial and apartheid non-economic constructions for subsidy to capitalist development.

Although a plethora of unpredictable uncertainties and risks impinge on all those who reside in rural areas (Anderson, 2003), rural women have remained the most vulnerable (Eshete, 1992; Koissy-Kpein, 2012; Tsheola, 2012). Equally, women have been at the coalface of rural communities' development through their momentous, diverse and innovative voluntary contributions within the private social household sphere and in dealing with local needs, services and maintenance of vibrant public community economies (Midgley, 2006). Women's unrecognized development practices have generally occupied the spaces between the private social household and public economic community domains, an artificial fissure created by the state and capital to serve the interests of the hegemonic capitalist development (Milroy and Wismer, 1994; Gibson-Graham, 1996; Marsden, 1996; Bob, 2001; Perrons, 2002; McDowell, 2006; Midgley, 2006). Historically, the state and the traded capital have thrived through the exploitation of the gendered socio-economic relations, rurality and communitarianism (Day, 1998; Ray, 2001). Thus, a fight against rural poverty under state capitalism will unavoidably be paradoxical because of the imperative to ensure that rural women empowerment, whereas a foundational block for reconstructing the gendered rurality and regenerating rural development, should not necessarily liberate women from serving the interests of the state and capital through their guarantees of subsidy for capitalist development. State attempts to reconstruct rural women's lives by establishing modern female biographies that are alien to local ruralities, should not be a surprise.

\subsection{The Rural "Private" Social Household and the "Public" Economic Community Spheres}

The chores of securing a living for rural households are disproportionately shouldered by women (Eshete, 1992; Baliamoune-Lutz and McGillivray, 2009; Koissy-Kpein, 2012), but their economic participation in rural development continues to be underrated due to the artificial separation of the household from the community as social and economic domains, respectively (Midgley, 2006). The hegemonic capitalist system has incubated and sustained a strong correlation among masculinity, progressive practices, productivity, independence, rational individualism and development (Poiner, 1990; Hanson and Pratt, 1995; Walby, 1997; Adkins and Lury, 1999; Meier et al., 2002; Perrons, 2002; Shortall, 2002; McDowell, 2006). These masculine constructions have implied that development is possible only "within the masculine public gender regimes of capitalism and the state" (Midgley, 2006, p.218).

Rural feminist debates have challenged these masculine constructions, demonstrating that women's lived experiences are not necessarily confined to the private social household sphere (Adkins, 1999, 2003; Adkins and Lury, 1999; McNay, 1999; Midgley, 2006; Bryant and Pini, 2009). But most rural economic practices have remained essentially feminized as "part of women's constructed (non-)economic identity(ies)" (Midgley, 2006, p.217). Additionally, women have voluntarily extended the "protection and maintenance of their personal and household economic status" into the public economic realm of the community by performing "female responsibility for community group and ... (by) subsequent maintenance of the community group's economic status" (Midgley, 2006, p.217). These development practices have remained obscured as survivalist despite the momentous subsidy they provide to the public rural economic community sphere (Eshete, 1992; Milroy and Wismer, 1994; Little, 1997b; Adkins, 1999, 2003; Adkins and Lury, 1999; McNay, 1999; Bob, 2001; Perrons, 2002; Midgley, 2006; Baliamoune-Lutz and McGillivray, 2009; Bryant and Pini, 2009; Koissy-Kpein, 2012). For this reason, feminist economic geography rejects the notion of separate private social household and public economic community spheres because rural women's feminized development practices points to the existence of intricate interconnections between these two domains (Milroy and Wismer, 1994; Laurie et al., 1999; Little, 2002; Meier et al., 2002; Little and Panelli, 2003; Midgley, 2006; Pini, 2005, 2006). Also, debates about the economic constructions of rural women's lives have uncovered the gendered constructions of rurality and the socioeconomic relations as well as how they affect development practices and roles within households and communities (Little 
and Austin, 1996; Little, 1997b, 2006; Little and Jones, 2000; Bob, 2001; Midgley, 2006; Panelli, 2006; Hoggart, 2007; Bryant and Pini, 2009; Koissy-Kpein, 2012; Tsheola, 2012).

In practice, the private social household domain mops-up the socio-economic externalities created by the market and the state in the public economic community sphere (Eshete, 1992; Milroy and Wismer, 1994; Midgley, 2006; Bryant and Pini, 2009; Bado 2012). Attempts at reconstructing rural women's lives for productive participation in the public economic sphere are, unavoidably, intricately bound with the "myths, assumptions and expectations about rural society and culture" (Little, 1997a, p.139). Thus, rural women's economic participation and, by implication, empowerment, are "reliant on a shift in hegemonic ideologies where the distinction and separation between social and economic are removed and skills and capabilities apparent and recognized in one area are not viewed as applicable or appropriate in another" (Midgley, 2006, p.229). But the present euphoria about women empowerment has hoped to reconstruct rural women's economic identities without transforming gendered rurality and communitarianism, and without altering the artificial separation between the private social household and the public economic community domains (Midgley, 2006; Bryant and Pini, 2009; Koissy-Kpein, 2012; Tsheola, 2012).

The paradox of state-funded women-oriented projects too is that they had hoped to empower rural women whilst the state and capital collude economically and ideologically, using state capitalism, to exploit their volunteerism and to legitimize capitalist development as a supplement, and sometimes replacement, for "state service provision, especially welfare services" (Little, 1997b, p.203). Rural women's development volunteerism is expected by the community, the state and the traded capital, implying that feminization of the public economic community sphere is promoted without altering the gendered rurality or transforming the gender exclusivity of the private feminine social and public masculine economic domains, and by keeping the prevailing socio-economic relations in tact (Midgley, 2006; Bryant and Pini, 2009; Koissy-Kpein, 2012; Tsheola, 2012). Ultimately, the artificial separation between the private social household and the public economic community domains militates against rural women empowerment (Midgley, 2006; Bryant and Pini, 2009; Tsheola, 2012).

\subsection{Rurality, Communitarianism and Non-economic Constructions of Women's Lives}

Traditionally, rural women's lives were constructed as social rather than economic, "with their agency positioned within the private rather than public sphere" (Midgley, 2006, p.229). These constructions have endured, with negligible "questioning or change" (Little and Austin, 1996, p.103), in developing countries. Consequently, rural women's development practices have remained "firmly" rooted in private household domain, entrenching the "wifehood and motherhood" chores in the non-economic constructions of their lived experiences (Milroy and Wismer, 1994; Little and Austin, 1996; Little, 2002; Midgley, 2006; Bryant and Pini, 2009; Koissy-Kpein, 2012). Whereas the shift in the rural socioeconomic relations created opportunities for increased proportions of women to participate in the formal economy, rural women's participation remained fundamentally incomplete because their development practices were only deemed "economic" if they mirrored the masculine economic attributes and actions (Eshete, 1992; Milroy and Wismer, 1994; Midgley, 2006; Baliamoune-Lutz and McGillivray, 2009; Bryant and Pini, 2009; Koissy-Kpein, 2012).

Rural women's lives and development practices have been constructed within the presumed oneness, indebtedness and obligation notion of community, which is embedded with the hegemonic capitalist economic thought (Eshete, 1992; Midgley, 2006; Tsheola, 2012). A strong linkage between rurality, communitarianism and women has been enforced through the ethic of care, survival and sustenance (material and social order) of household, which is itself deeply embedded with feminine characterization of the hegemonic neoliberal economics (Shortall, 2002; Koissy-Kpein, 2012). Thus, gendered rural development under state capitalism would inevitably mean that women empowerment projects are conceived through prisms of "male norms" and "traditional rural gender ideologies" that promote and sustain the masculine economic regimes of capitalism (Eshete, 1992; Little and Jones, 2000; Bado, 2012; Tsheola, 2012). Ultimately, the state and capital collude to affirm ideologies of communitarianism and to reproduce power relations wherein the material bases within the rural economies is driven by gendered divides and men's exclusive access and control over productive resources (Poiner, 1991; Bryant and Pini, 2009; Koissy-Kpein, 2012).

Whereas rural communities are not internally homogeneous, communitarianism implies shared social, consumption, cultural and lifestyle preferences; and, in most developing countries "rurality is constructed as communitarianism" (Bryant and Pini, 2009, p.52). Inevitably, rurality has remained deeply gendered (Panelli, 2006; Tsheola, 2012) with a strong association between women and communitarianism; also, class has been critical to the gendering of rural spaces (Pini, 2005, 2006, 2007; Bryant and Pini, 2009). Therefore, "gender and class are intricately connected in rural spaces" and, are on an ongoing basis, "actively constructed and reconstructed through daily 
interactions, the nature of one's work, volunteer activities, leisure choices and memories" (Bryant and Pini, 2009, p.55). Hence, rural women's pluriactivity is not necessarily an open, free choice (Tsheola, 2012).

Hoggart (2007) and Phillips (2007) underlined the significance of understanding the implications of the social and cultural constructions of the gendered rural spaces in rural regeneration and development. Notwithstanding the currency of democratization, rurality and gender remain firmly inscribed in rural economies in multifaceted and diverse ways that are heavily dependent on the specific population's values and culture (Bryant and Pini, 2009; Tsheola, 2012). The hegemonic constructions of the "good mother" too portray a woman as enthusiastically participating in paid work and consumption (Little, 1997a, 1997b; Aufhauser and Hafner, 2002; England and Glad, 2002; Meier et al., 2002; Perrons, 2002; McDowell, 2006; Koissy-Kpein, 2012) whilst simultaneously "purchasing the labor of working-class women for domestic services" (Bryant and Pini, 2009, p.51). Consequently, debates of value and worth, or lack thereof, attached to motherhood invoke defense and rejection of paid work wherein "the moral worth of working class women is in question as their personhood is deemed lacking against media portrayals of middle class standards" (Bryant and Pini, 2009, p.51). In South Africa, therefore, rural women-oriented projects thrust women into the capitalist class processes without restructuring the deeply gendered space economies and relations, accentuated through colonial and apartheid capitalism. The ability of rural women to make "multiple and individual choices" about how to live their lives is in most developing countries intricately bounded and embedded with the gendered rurality of communitarianism (Tsheola, 2012).

Social and cultural structures of the gendered rural spaces are critical to rural restructuring, regeneration, women empowerment and development (Shortall, 2002; Midgley, 2006; Pini, 2005, 2006; Bryant and Pini, 2009). The hope to merely engender gentrification of rural communities through women-orientation projects presupposes that traditional livelihoods, culture, consumption and lifestyle preferences could be purchased and substituted with new ones (Marsden, 1996; Phillips, 1998, 2002; Bryant and Pini, 2009). Given this false hope, women's contributions to rural economies and development continue to be "obscured or ignored"; and, rurality remains characterized by hegemonic traditional gender and communitarianism discourses, uncodified scripts and practices (Milroy and Wismer, 1994; Midgley, 2006; Baliamoune-Lutz and McGillivray, 2009; Bryant and Pini, 2009; Koissy-Kpein, 2012). Whereas unevenly, rural women have been virtually invisible and disadvantaged (Little and Panelli, 2003; Little, 2006) as the private household sphere assumed primacy within rural spaces wherein "personal labor and love" coalesced in a paradoxical fashion that entrenches the most enduring consciousness of gendered rurality and communitarianism (Hey, 2003; Midgley, 2006).

Women-oriented projects in developing countries are equally trapped in the unrealistic notion of homogenization of rural women, thereby paradoxically reinforcing the traditional patriarchal socio-economic relations and the artificial separation of the private household sphere as a social feminine domain, from the public community sphere as an economic masculine domain (Hey, 2003; Midgley, 2006; Koissy-Kpein, 2012). Women's biographic transitions are paradoxically promoted amidst continued requirement of their voluntary practices which are however underrated within capitalist development (Tsheola, 2012). Rather than deconstruct women's lived experiences, these projects reinforce the mutual constitutive relations of gender with identities such as class, race, religion, tradition, sexuality, and so on (Laurie et al., 1999; Pini, 2005) under state capitalism. The skeletons of failed reforms across rural South Africa's former Bantustans, almost 18 years after democratization, suggest therefore that "policies, institutions and market mechanisms" that impact upon constructions of rural women's lived experiences, require continuing scrutiny (Anderson, 2003, p.188).

\subsection{Paradoxes of Women Economic Constructions and Empowerment under State Capitalism}

The foundational principle underlying women-oriented development projects is to liberate women from their traditional roles and to assist them establish independent modern biographies for participation in the formal economy (Aufhauser and Hafner, 2002; Tsheola, 2012). The state-funded projects seek to empower rural women so that they may be autonomous, whilst simultaneously deconstructing "the existing asymmetrical gender order" and supporting "individual women in designing a self-determined biography" (Aufhauser and Hafner, 2002, p.258). But such women-oriented projects have inadvertently reinforced "a gender-differentiated interpretation of socio-economic needs and a genderdifferentiated construction of identities ... (as well as) ... traditional images of femininity without upgrading them qualitatively" (Aufhauser and Hafner, 2002, p.258, 259). Rather than transform the "structural gender inequality" and assist women to attain "self-realization", self-determination, self-enhancement and beneficial "integration" of the private household chores into the formal economy, such projects have disempowered rural women (Koissy-Kpein, 2012; Tsheola, 2012). They reinstituted the gendered rurality and affirmed the strong association between women and communitarianism, to the exclusive benefit of the state and capital, under state capitalism. Hence, rural women continue to be viewed as "a homogeneous group of mothers" "handicapped" and rendered "imperfect" by their reproductive duties, 
in an assumedly "perfect" capitalist market world-economy (Meier et al., 2002, p.246). Their non-economic constructions persist as the "social and gender divisions are being reproduced in the new (globalized and modernized) economy" (Perrons, 2002, p.272) through the artificial separation of the private social and public economic domains (Midgley, 2006; Bryant and Pini, 2009; Koissy-Kpein, 2012).

Rather than empower women, feminization of the capitalist rural economies has primarily entailed a complex balancing act for rural women, requiring them to simultaneously manage formal work and household responsibilities (Bob, 2001; England and Gad, 2002; Koissy-Kpein, 2012; Midgley, 2006). Women who are perceived to be empowered are in practice trapped in a paradox that forces them to either manage family businesses that require skills and knowledge compatible with their household circumstances, or to work part-time or as casual labor, or to work unsociably long hours (Midgley, 2006; Koissy-Kpein, 2012). Women empowerment projects have not disentangled this traditional association between rural women, communitarianism and the private household "economy of affection" (Midgley, 2006; Koissy-Kpein, 2012; Tsheola, 2012). These projects have not restructured the rigid social and cultural context underlying the gendered rural household responsibilities for women. Instead, they have sought to establish independent female biographies, whose performance cannot be motivated within the rural localities because the conditions required for raising motivation for performance, are virtually absent.

Evidently, the hegemonic macro-policies are not only androcentric, they are also patriarchal and they enforce a context within which projects conceived as women-oriented essentially service men's development agendas and interests (Bado, 2012; Tsheola, 2012). Reconstructions of rurality have remained ironically patriarchal and androcentric, especially in decision-making processes (England and Gad, 2002; Meier et al., 2002; Perrons, 2002; Bado, 2012; Koissy-Kpein, 2012). Rurality and communitarianism continue to be deeply gendered with a strong culture of "male-breadwinnersfemale-caregivers" (Perrons, 2002) under state capitalism where the "biographical orientations of women" remain deeply paradoxical (Aufhauser and Hafner, 2002), whilst the state and capital derive benefits (Midgley, 2006; Koissy-Kpein, 2012). Given the apparent women empowerment paradoxes, rural feminism inescapably urges for a social welfare state that supports women's participation in the formal economy by providing for "childcare, care facilities for the elderly, the social security system" as well as "parental leave schemes" in the hope of liberating women from their "traditional roles as caregivers" (Meier et al., 2002, p.244, 245). In practice, another woman is afforded a lower class paid employment to liberate a working mother for the formal economy (Midgley, 2006; Bryant and Pini, 2009). Unsurprisingly, the notion of successful women closing the doors behind them is increasingly gaining traction because they are themselves exploited in the interactions of the state and capital for continued provision of subsidy to capitalist development.

\section{South Africa's Rural Development Policy and Limpopo Province Rurality}

Whereas a democratic South Africa adopted a variety of reforms to redress gender inequalities, rural women have continued to be subjected to relatively inferior standards of living and degraded quality of life (Bob, 2001; D'Haese and van Huylenbroeck, 2005; Jacobs et al., 2008). Rural poverty persists also as a "negative product" of well-intended, but poorly conceived interventions like structural adjustments (Nabudere, 2006; Tsheola, 2012). Bob (2001) notes that poor theoretical comprehension of former Bantustan economies can, potentially, frustrate even the well-intended development strategies. The hyperbolic insinuation that rural women could be provided with capital, jobs, income, skills and knowledge through state-funded projects has remained a pipedream due to the predominance of the neoliberal ethos of the 1997 rural development policy (Tsheola, 2012).

\subsection{South Africa's Neoliberal Rural Development Policy}

South Africa adopted a new rural development policy in 1997 (Department of Land Affairs, 1997), seeking to achieve poverty alleviation by shifting rural communities away from subsistence-oriented agriculture to market-oriented development through market deregulation and liberalization (D'Haese and van Huylenbroeck, 2005; Cousins, 2007; Jacobs et al., 2008; Traub and Jayne, 2008). The enforcement of market economics in rural spaces was precipitated by GEAR, a 1996 neoliberal macroeconomic policy, which entrenched the market as the primary driver of national development (D'Haese and van Huylenbroeck, 2005; Cousins, 2007; Jacobs et al., 2008; Traub and Jayne, 2008; Tsheola, 2012). Whereas the rhetoric suggested that the rural development policy sought to balance state development intervention with GEAR's requirement for "maintenance of a sound fiscal and macro-economic framework" (DLA, 1997, p.7), in practice GEAR enforced rural market deregulation and liberalization, creating a deeply competitive market structure (D'Haese and van Huylenbroeck, 2005; Cousins, 2007; Jacobs et al., 2008; Traub and Jayne, 2008). 
South Africa's rural development policy is best described through the agricultural market deregulation which "coincided with macro-level political economy reforms", that were initiated through the 1984 White Paper on Agriculture (Jacobs, 2008, p.8). This White Paper imposed far-reaching market-oriented reforms; and, the post-apartheid Marketing of Agricultural Products Act No 47 of 1996 provided for the integration of smallholder producers into the agricultural market (Jacobs, 2008, 2009; Traub and Jayne, 2008). Section 2 of the Act extends deregulation and liberalization to all other spheres of agriculture, whereas Sections 2(2) and 16 thrust smallholders into agricultural export chains (Jacobs, 2008, 2009). The 2001 Strategic Plan for Agriculture merely endorses this market-oriented approach and accepts that supermarket chains have become dominant in the agro-food value chains, where they are powerful in negotiating and determining producer prices, locally and internationally (Jacobs, 2008, 2009). Since at least 1996, the agricultural marketing policies have sought to liberalize and deregulate the full agricultural value chain in line with the GEAR macroeconomics (Jacobs, 2008, 2009; Traub and Jayne, 2008). As the four dominant supermarket chains (Shoprite, Pick 'n Pay, Spar and Woolworths), expanded their activities into the countryside since 2005, the rural Bantustan vendors, small shops and spazas increasingly came under attack (D'Haese \& van Huylenbroeck, 2005). In practice, supermarket expansion into countryside intensified the exposure and vulnerability of poor rural households to poverty, whilst conversely benefiting large commercial farmers, leading to the accentuation of the stark colonial and apartheid capitalism inequalities.

Paradoxically, the policy hoped to simultaneously place women empowerment at the center of sustainable rural development (DLA, 1997), implying that women-oriented projects were framed along free market mechanisms. Whereas state capitalism, privatization, flexibilization and deregulation remained fundamentally male-oriented within the gendered rurality of former Bantustans, the latter had poor prospects of financial and economic sustainability as well as virtual absence of economic opportunities. The tension between the goals of fiscal discipline and the imperatives of poverty alleviation has remained palatable (Marais, 2001; Tsheola, 2012). Whereas government made "a specific commitment to invest in rural areas" (Marais, 2001, p.184), rural women's plight remained tenuous.

\subsection{South Africa's Women-oriented Projects and Rural Limpopo Province Contexts}

Government has since 1994 implemented a variety of state-funded projects, within the frameworks of the national public works, in the hope of generating temporary jobs and providing skills for women, youth and disabled, and for creating minimum social rural infrastructure base (Khosa, 2002). The fundamental assumption to these projects was that rural women were helpless "housekeepers" (Khosa, 2002), thereby obscuring their longstanding practices of survivalist livelihoods (Tsheola, 2012). Consequently, the projects compounded the historical weakening of rural women's informal associations, rendering them less powerful and invisible (Khosa, 2002; Tsheola, 2012). The greater financial and social benefits to households that rural women have historically made, was consistently undermined simultaneously as remittance transfers, pluriactivity and state social grants gained currency (McCusker, 2002; Tsheola, 2012). With the ascendency of state capitalism and the worsening ecological crises, migrant remittances, non-farm strategies and social welfare became preeminent among rural households (Bryceson, 1997, 1999, 2000; McCusker, 2002). Presently, rural communities living in tribal settlements of former Bantustans in Limpopo Province are, for example, earning negligible or no income from agricultural activities (Bryceson, 1997; Francis, 2000, 2002; Bob, 2001; McCusker, 2002; D'Haese and van Huylenbroeck, 2005; Cousins, 2007; Jacobs et al., 2008; Traub and Jayne, 2008; Tsheola, 2012).

Limpopo Province, which encompasses former Bantustans of Venda, Gazankulu and Lebowa with 89 percent rurally-based population, typifies a grim reality of poverty where 77 percent of households receive less than R3000 per month (RSA, 2007). The provincial unemployment rate was about 54 percent, with a Human Development Index of 0.47 and a dependency gap of 7.1 (Limpopo Provincial Government, 2001). Women constituted 55 percent of the provincial population compared to the national proportion of 52.2 in 2006 (RSA, 2007). Most of the drudgery involved in collection of water and firewood, childcare and care for the aged and the infirm in the province, has largely remained women's responsibility (McCusker, 2002; Jacobs et al., 2008; Tsheola, 2012). Understandably, rural development had to focus on women empowerment in order to increase their chances of becoming self-employed or of entering the formal economy (RSA, 1995). But this goal was pursued through gendered projects that were embedded with paradoxical selfish interests of the state and capital, within an unforgiving rurality, androcentrism and state capitalism.

\section{Conclusion}

Theoretically, this paper argued that under state capitalism and the Trojan flag of democratization, the state and capital 
collude to perpetuate gendered discrimination and exploitation of rural women, which were incubated through colonialism and apartheid, for subsidy to capitalist development. The fallacious and artificial separation of women's private household as social sphere from the public community as the masculine productive economic domain paradoxically underwrites the women empowerment rhetoric and women-oriented projects. Instead, these projects have in practice deepened rural women's uncertainties and vulnerabilities to poverty and gendered discrimination by enticing them away from their survivalist livelihoods, only to engender increased reliance on dependency-oriented strategies.

The paper concludes that the presumption that women empowerment entails the establishment of independent modern female biographies required for performance in the formal economy is a misleading paradox for former Bantustans in South Africa and, by extension, for developing countries whose political-economy was (re)shaped through colonial capitalism. Given the goodness inherent in the concepts of women empowerment and democratization, and the unquestioning adoption of state capitalism by developing countries, this paper should raise vexed enquiries about the persistence of gendered rurality, exploitation of women for subsidy to capitalist development and the underlying motives for the convergence of the state and capital or traded market.

\section{References}

Adkins, L., 1999. Community and economy: a retraditionalization of gender? Theory, Culture and Society 16(1), pp.119-139.

Adkins, L., 2003. Reflexivity: freedom or habit of gender? Theory, Culture and Society 20(6), pp.21-42.

Adkins, L. and Lury, C., 1999. The labor of identity: performing identities, performing economies, Economy and Society 28(4), pp.598-614.

Anderson, J.R., 2003. Risk in rural development: challenges for managers and policy makers. Agricultural Systems 75(2-3), pp.161-197.

Aufhauser, E. and Hafner, S., 2002. Feminism and the new multi-scaling in employment policy. GeoJournal 56(4), pp.253-260.

Bado, N., 2012. Community driven development: a viable approach to poverty reduction in rural Burkina Faso. African Development Review 24(1), pp.34-40.

Baliamoune-Lutz, M. and McGillivray, M., 2009. Does gender inequality reduce growth in Sub-Saharan African and Arab countries? African Development Review 21(2), pp.224-242.

Bob, U., 2001. The intersection of gender, race and class: the socio-economic and spatial implications of differentiation in the former Homelands of South Africa. South African Geographical Journal 83(3), pp.190-197.

Bond, P., 1999. Basic infrastructure for socio-economic development, environmental protection and geographical desegregation: South Africa's unmet challenge. Geoforum 30, pp.43-49.

Bond, P., 2004. Talk Left, Walk Right: South Africa's Frustrated Global Reforms. University of KwaZulu-Natal Press, Scottsville.

Bryant, L. and Pini, B., 2009. Gender, class and rurality: Australian case studies. Journal of Rural Studies 25(1), pp.48-57.

Bryceson, D., 1997. Farewell to Farms: De-agrarianisation and Employment in Africa. Ashgate, Hampshire.

Bryceson, D., 1999. African rural labour, income diversification and livelihood approaches: a long-term development perspective. Review of African Political Economy 26(80), pp.171-189.

Bryceson, D., 2000. Rural Africa at the crossroads: livelihood practices and policies. Overseas Development Institute, London.

Caporaso, J.A. and Levine, D.P., 1992. Theories of Political Economy. Cambridge University Press, Cambridge.

Cousins, B., 2007. Agrarian reform and the "two economies": transforming South Africa's countryside. In Ntsebeza, L. and Hall, R., Editors, 2007. The Land Question in South Africa: the Challenge of Transformation and Redistribution, HSRC Press, Cape Town.

Clapham, C., 2001. Rethinking African states. African Security Review 10(3), pp.6-16.

Clapham, C., 2002. The challenge to the state in a globalized world. Development and Change 33(5), pp.775-795.

Day, G., 1998. Working towards the grain? Towards sustainable rural and community development. Journal of Rural Studies 14(1), pp.89-105.

Dempsey, K., 1992. A Man's Town: Inequality between Women and Men in Rural Australia. Oxford University Press, Melbourne.

Department of Land Affairs (DLA), 1997. Rural Development Framework. Government Printers, Pretoria.

D'Haese, M. and van Huylenbroeck, G., 2005. The rise of supermarkets and changing expenditure patterns of poor rural households case study in the Transkei area, South Africa. Food Policy 30, pp.97-113.

England, K. and Gad, G., 2002. Social policy at work? Equality and equity in women's paid employment in Canada. GeoJournal 56(4), pp.283296.

Eshete, A., 1992. Population and women in development: gender issues in the context of population and development. African Development Review 4(1), pp.79-117.

Francis, E., 2000. Making a Living: Changing Livelihoods in Rural Africa. Routledge, London.

Francis, E., 2002. Rural livelihoods, institutions and vulnerability in North-West Province, South Africa. Journal of Southern African Studies 28(3), pp.531-550.

Gibson-Graham, J., 1996. The End of Capitalism as we Knew it: a Feminist Critique of Political-economy. Blackwell, Oxford.

Hall, A. and Midgley, J., 2004. Social Policy for Development. London: SAGE.

Hammett, D. 2010. Zapiro and Zuma: a symptom of an emerging constitutional crisis in South Africa? Political Geography 29, pp.88-96.

Hanson, S. and Pratt, G., 1995. Gender, Work and Space. Routledge, London.

Hettne, B., 1995. Development Theory and the Three Worlds, Second Edition. Longman, Essex.

Hey, V., 2003. Joining the club? Academia and working-class femininities. Gender and Education 15(2), pp.319-35.

Hoggart, K., 2007. The diluted working classes of rural England and Wales. Journal of Rural Studies 23(3), pp.305-317.

Jacobs, P., 2008. Market development and smallholder farmers: a selective literature survey. Background paper for the Second Economy Project. October 2008, Pretoria, HSRC. 
Jacobs, P., 2009. Agricultural market reforms and the rural poor in South Africa. Research Paper of the 2009 PLAAS Poverty Workshop, Cape Town.

Jacobs, P., Aliber, M., Hart, T. and O'Donovan, M., 2008. Review of Rural Development: 15 Years Review of Economic and Social Sector Programmes. HSRC Press, Pretoria.

Khosa, M.M., 2002. (Dis)Empowerment through social transformation in South Africa. South African Geographical Journal 84(1), pp.21-29.

Koissy-Kpein, S., 2012. Gender and competition between economic or non-economic labour and schooling: evidence from EPAM Mali. African Development Review 24(1), pp.107-123.

Laurie, N., Dwyer, C., Holloway, S. and Smith, F., 1999. Geographies of New Femininities. Pearson, Harlow.

Little, J., 1997a. Employment marginality and women's self-identity. In Cloke, P. and Little, J., Editors, 1997. Contested Countryside Cultures: Otherness, Marginality and Rurality, Routledge, London.

Little, J., 1997b. Constructions of rural women's voluntary work. Gender, Place and Culture 4(2), pp.197-210.

Little, J., 2002. Gender and Rural Geography. Prentice Hall, Harlow.

Little, J., 2006: Gender and sexuality in rural communities. In Cloke, P., Marsden, T. and Mooney, P.H., Editors, 2006. Handbook of Rural Studies, Sage, London.

Little, J. and Austin, P., 1996. Women and the rural idyll. Journal of Rural Studies 12(2), pp.101-111.

Little, J. and Jones, O., 2000. Masculinity, gender, and rural policy. Rural Sociology 65(4), pp.621-639.

Little, J. and Panelli, R., 2003. Gender research in rural geography. Gender, Place and Culture 10(3), pp.281-290.

Mabogunje, A.L., 1989. The Development Process: a Spatial Perspective, Second Edition. Unwin Hyman, London.

Marais, L., 2001. Towards a policy framework for post-apartheid housing investment in former Homeland areas: evidence from the Free State. South African Geographical Journal 83(3), pp.183-189.

Marsden, T., 1990. Towards the political-economy of pluriactivity. Journal of Rural Studies 6(4), pp.375-382.

Marsden, T., 1996. The social and political bases of rural restructuring. Progress in Human Geography 20(2), pp.246-258.

McCusker, B., 2002. The impact of membership in Communal Property Associations on livelihoods in the Northern Province, South Africa. GeoJournal 56(2), pp.113-122.

McDowell, L., 2006. Reconfigurations of gender and class relations: class differences, class condescension and the changing place of class relations. Antipode 38(4), pp.825-850.

McNay, L., 1999. Gender, habitus and the field: pierre bourdieu and the limits of reflexivity. Theory, Culture and Society 16(1), pp.95-117.

Meier, V., Schier, M. and von Streit, A., 2002. Geography and gendered labour markets. GeoJournal 56(4), pp.243-251.

Midgley, J., 1999. Growth, redistribution and welfare: towards social investment. Social Service Review 77(1), 181-188.

Midgley, J., 2006. Gendered economies: transferring private gender roles into the public realm through rural community development. Journal of Rural Studies 22(2), pp.217-231.

Milroy, B.M. and Wismer, S., 1994. Communities, work and public/private sphere models. Gender, Place and Culture 1(1), pp.71-90.

Nabudere, D.W., 2006. Development theories, knowledge production and emancipatory practice. In Padayachee, V., Editor, 2006. The Development Decade? Economic and Social Change in South Africa, 1994-2004, HSRC Press, Cape Town.

Panelli, R., 2006. Rural society. In Cloke, P., Marsden, T. and Mooney, P.H., Editors, 2006. Handbook of Rural Studies, SAGE, London.

Peet, R., 2002. Ideology, discourse, and the geography of hegemony: from socialist to neoliberal development in post-apartheid South Africa. Antipode 34(1), pp.54-84.

Perrons, D., 2002. Gendered divisions in the new economy: risks and opportunities. GeoJournal 56(4), pp.271-281.

Phillips, M., 1998. The restructuring of social imaginations in rural geography. Journal of Rural Studies 14(2), pp.121-153.

Phillips, M., 2007. Changing class complexions on and in the British countryside. Journal of Rural Studies 23(3), pp.283-304.

Pini, B., 2005. The third sex: women leaders in Australian agriculture. Gender, Work and Organization 12(1), pp.73-88.

Pini, B., 2006. A critique of new regional governance: the case of gender in a rural Australian setting. Journal of Rural Studies 22(4), pp.383-402.

Pini, B., 2007. Always an outlaw: daughters-in-law on Australian family farms. Women's Studies International Forum 30(1), pp.40-44.

Poiner, G., 1990. The Good Old Rule: Gender and Other Power Relationships in a Rural Community. Sydney University Press, Sydney.

Poiner, G., 1991. Women and the Academic Procession: Questions of Equality and Opportunity. Women's Research Centre, Kingswood.

Ray, C., 2001. Culture Economies. Centre for Rural Economy, University of Newcastle.

Republic of South Africa (RSA), 1995. Rural Development Strategy. Government Printers, Pretoria.

Republic of South Africa (RSA), 2007. Development Indicators Mid-term Review. Government Printers, Pretoria.

Shortall, S., 2002. Gendered agricultural and rural restructuring: a case study of Northern Ireland. Sociologia Ruralis 42(2), pp.160-175.

Smith, L., 2004. The murky waters of the second wave of neoliberalism: corporatization as a service delivery model in Cape Town. Geoforum 35 , pp.375-393.

Traub, L.N. and Jayne, T.S., 2008. The effects of price deregulation on maize marketing margins in South Africa. Food Policy 33, pp.224-236.

Tsheola, J. 2012. Rural women's survivalist livelihoods and state interventions in Ga-Ramogale Village, Limpopo Province. African Development Review 24(3), pp.221-232.

Tsheola, J. and Sebola, M. 2012. Post-apartheid public service delivery and the dilemmas of state capitalism in South Africa, 1996-2009. Journal of Public Administration 47(1.1), pp.228-250.

Walby, S., 1997. Gender Transformations. Routledge, London.

Wooldridge, A., 2012. State capitalism: the visible hand. The Economist 402(8768), pp.1-18. 